\title{
У ПОШУКАХ ПІЗНАННЯ ПІДНЕБЕСНОЇ. РОЗВІНЧАННЯ УКРАЇНСЬКИЙ СТЕРЕОТИПІВ ПРО КИТАЙ
}

\author{
Марія Попова \\ Київський університет імені Бориса Грінченка \\ Київ, Україна \\ ORCID: 0000-0002-6830-9683
}

\section{IN SEARCH OF KNOWLEDGE OF THE CELESTIAN EMPIRE. DEBUNKING UKRAINIAN STEREOTYPES ABOUT CHINA}

\begin{abstract}
The article examines the stereotypes of foreign students of Chinese universities on the Chinese people, and the influence of stereotypes on the formation of world outlook in foreign students in relation to the Celestial Empire. The results showed that foreign students have changed their attitude to Chinese students after study in China.
\end{abstract}

Key words: stereotype, Chinese national character, culture, Symbol, scattering, China, Ukraine.

Іноземці, які ніколи не були в Китаї, дуже туманно розуміють цю країну. Недостатня обізнаність про Середнє царство призводить до того, що в нашому суспільстві протягом десятиліть культивуються одні й ті ж міфи. Уявлення про Китай в українському суспільстві існують у формі образів та стереотипів. Сприйняття та розуміння китайського народу часто є помилковим, тому існують фактори, які заважають правильно сприймати та оцінювати людей.

Китайська цивілізація вважається однією $з$ найдавніших у світі. Ї̈ї підтверджений археологічними знахідками вік, становить не менше трьох 3 половиною тисяч років. Світова громадськість пильно стежить за розвитком сучасного Китаю, при цьому країна багато в чому залишається за гранню нашого розуміння. Цікаво, що навіть поширена в вітчизняних джерелах неофіційна назва країни, яка звучить як "Піднебесна", $€$ помилковим ототожненням китайської філософської категорії з географічною назвою.

Довгий час Китай був абсолютно закритою країною. Відсутність контактів з іншими цивілізаціями вводило китайців в оману щодо географічного розташування та унікальності свого державного утворення. Жите- 
лі Давнього Китаю вважали, що вони знаходяться в центрі світу, звідси і випливає поняття "Чжунго", тобто “Центральна держава".

Але існує друга назва Китаю “Піднебесна" (天下). Ця назва згадується ще за часів першого китайського державного утворення - династії Шан (1600-1046 д.н.е.).

Термін 天下 є китаєцентричною філософією, під якою розуміється весь світ, тобто все, що є “під Небом". У широкому сенсі цього слова розуміється безмежний (світ), а у вузькому сенсі - певний географічний обмежений простір (держава імператора). Термін "Піднебесна" мав на увазі під собою ототожнення з усім світом, але не з Китаєм окремо. 3 того часу і по теперішній день в Китаї під "Піднебесною" мають на увазі весь світ. Світоглядна система у Східній Азії, за якою у цілому світі, наповненому “варварами”, лише Китай є центром цивілізації, культури і філософії, а також головним просвітителем “варварських" народів. Ця система обгрунтовувала провідну роль Китаю в регіоні і світі впродовж двох останніх тисячоліть.

Використання терміна "Піднебесна" по відношенню до сучасного Китаю не коректне і являється стереотипом. Більш вірним є ототожнення Китаю 3 “Чжунго". Крім того, ієрогліфи 中国 використовуються і в назві Китайської Республіки, що виникла в 1912 році і Китайської Народної Республіки, заснованої в 1949 році.

Незважаючи на велику колекцію стародавніх артефактів, які постійно поповнюється завдяки китайським археологам і систематизуються дослідниками з КНР, до сих пір в Україні існує цілий ряд поширених помилок про Китай.

Стереотипи - когнітивна структура людей та специфічні когнітивні закономірності з їх відносно постійною ідеєю або очікуванням членів в одній певній групі, і вони допомагають керувати соціальними пізнаннями та поведінкою людей ${ }^{1}$. Стереотипи можуть спростити процес пізнання людей і зменшити навантаження на пізнання. За допомогою стереотипів люди можуть швидко отримати концепцію зазначених об'єктів, побудувати явні відносини між собою, об'єктами та добре визначають поведінку конкретних об'єктів ${ }^{2}$. Стереотипи можуть бути точними за певних обставин, але також можуть змусити людей ігнорувати інформацію, протилежну вже існуючим стереотипам і зробити неправильні судження.

За останні 10 років кількість студентів, які приїжджають до Китаю, зростає, і навчання за кордоном стало важливою групою китайського

Amy J. C. Cuddy, et al., Stereotype Content Model across Cultures: Towards Universal Similarities and Some Differences, "British Journal of Social Psychology" 2009, № 48.

2 S. Jin, Social Psychology (社会心理学), Beijing 2005. 
суспільства. Відмінності поміж китайською та українською культурами можуть призвести до непорозумінь і навіть конфліктів при спілкуванні 3 китайцями ${ }^{3}$. Тому особливо важливо знайти шляхи зменшення комунікативних бар'єрів та сприяння дружнім стосункам між іноземними студентами та китайцями.

Відповідно до контактної гіпотези, висунутої ALLPort, міжгруповий контакт може сприяти більш точному розумінню та зменшити стереотипи ${ }^{4}$. Ядром гіпотези є несправне незнання, яке передбачає, що формування стереотипів та ставлення від нестачі однієї групи адекватної інформації про іншу групу або певну неправильну інформацію, тоді як контекст контакту дає можливість отримати нову інформацію. У порівнянні з деякими іноземцями, які ніколи не були в Китаї, у тих студентів, хто був у Китаї, більше шансів контактувати з місцевими жителями. Таким чином, ці дві групи людей матють відмінності у своїх стереотипах щодо китайців.

У процесі соціальної взаємодії люди, природно, узагальнюватимуть і зміцнюватимуть характеристики різних груп, що призводить до соціальних стереотипів, включаючи національні стереотипи, гендерні стереотипи, регіональні стереотипи тощо 5 . У відносинах 3 китайцями У минулому іноземні студенти природним чином узагальнювали характеристики китайців і формували стереотип про китайців; серед них залишаться негативні стереотипи.

Студенти мають упередження щодо китайців, що призводить до непорозумінь та конфліктів у спілкуванні та негативно впливає на міжкультурну адаптацію. У дослідженні психологів Деніала Катца та Кеннета Брейлі (Расові стереотипи ста студентів коледжу) ${ }^{6}$ - зазначалося, що хоча велика кількість досліджень вивчала стереотипи іноземців щодо китайців але суб'єкти цих досліджень ніколи не були в Китаї чи рідко контактували з корінними мешканцями.

Дослідження показало, що стереотипи іноземних студентів щодо країни чи громадян тієї країни, де вони навчаються за кордоном, зміняться до та після виїзду за кордон. Тому на даний час важливим є вивчення життя іноземних студентів в Китаї, для того, щоб дослідити зміст і структуру їх стереотипів щодо китайців та відповісти на питання: який образ китайця в очах іноземних студентів? Які розміри китайських стереотипів? Чи впливає час приїзду до Китаю на китайські стереотипи?

3 姜良杰、汤明润, 来华留学生跨文化适应问题及对策, “人民论坛” 2012 , 《第 5 期.

4 Y. Li, J. Fan, Foreign Language Teaching and Research, “外语教学与研究” 2007.

5 丁慧芬, 蒙汉大学生民族刻板印象的结构及差异研究》, 内蒙古师范大学硕士学 位论文 2011 .

$6 \quad$ D. Katz, K. Braly, Racial Stereotypes of One Hundred College Students, "The Journal of Abnormal and Social Psychology” 1933, № 28, c. 280-290. 
Який зв'язок між цими стереотипами та ставленням іноземних студентів до китайців?

Стереотипи - це когнітивні структури та специфічні соціальні пізнання, що складаються з відносно фіксованих уявлень людей або очікувань членів певної групи. Схема має провідний вплив на соціальне пізнання та поведінку людей․ Стереотипи можуть спростити сприйняття людей Процес зниження когнітивного навантаження. Завдяки стереотипам люди можуть швидко отримати поняття про конкретний об'єкт і встановити чіткі стосунки між собою та об'єктом.

Професор психології Джей У. Джексон у своїй праці Ставлення до азіатських американщів: теорія та вимірювання поділив структуру стереотипів на позитивну (ентузіазм, гостинність, кропітка праця, наполеглива праця, негативну (звертаючи уваги на гігієну, галасливість, а головним чином включаючи негативні аспекти поведінки), нейтральні (любов до грошей, самолюбство, економія, переважно включаючий спосіб життя) ${ }^{8}$.

Позитивні стереотипи - це ентузіазм (включаючи гостинність та ввічливість китайського народу). Ентузіазм та гостинність, у свою чергу, відображає образ китайців, які ввічливо ставляться до іноземних студентів. Здібності китайського народу (включаючи працьовитість, допитливість, кмітливість, старанність та працьовитість), також $є$ позитивними стереотипами.

Дослідження показало, що стереотипи Позитивних рис можуть також викликати негативне ставлення. Хоча ці риси $€$ позитивними, висока здатність до старанності та працьовитості також може призвести до відчуття огиди чи ревнощів закордонних студентів до китайців.

На своєму досвіді можу сказати, що під час перебування в Китаї, найрозумнішими та найпрацьовитішими в нашій групі були саме студенти 3 Китаю, а через бажання презентувати свою країну з найкращої сторони, позитивні стереотипи китайського населення викликали в мене негативні емоції.

Негативні стереотипи - це поведінка (у тому числі гігієна та шум). Ці два негативні стереотипи викликанні специфічною поведінкою китайців (наприклад, сміття в кімнатах, куріння у приміщенні, плювання, недотримання правил дорожнього руху).

Нейтральні стереотипи - спосіб життя (включаючи любов до грошей, самолюбство та економію). Ці стереотипи, у порівнянні $з$ двома попередніми, $є$ унікальними: такі стереотипи можуть стати зрозумілими лише

\footnotetext{
7 管健, 刻板印象模型从内容模型到系统模型的发展与应用, “心理科学进展” 2009, 第 4 期.

8 H. Colin, J. W. Jackson, Attitudes toward Asian American: Theory and Measurement, "Journal of Applied Social Psychology" 2001, т. 31, вип. 8.
} 
в спілкуванні з китайцями або у випадку вивчення китайської культури. Варто зазначити, що ставлення іноземних студентів до нейтральних стереотипів досить різне. Деякі студенти вважають, що любов до грошей - це правильно, у той час як деякі вважають, що любити гроші - це дуже погана якість; деякі іноземні студенти вважають, що самолюбство - це захист репутації та гідності, а інші вважають, що самолюбство - це лицемірно; деякі іноземні студенти вважають, що економія - це чеснота, а деякі - те, що економія це витрачання грошей для того, щоб їх знову заробити. Ці відмінності у ставленні можуть бути особистісним досвідом або культурним походженням студента пов'язані між собою.

Також хочу зазначити, що у сучасних студентів щодо китайців немає таких стереотипів, як вірність родині та любов до традицій (які також можна віднести до позитивних стереотипів). Це може бути викликано тим, що зі зміною часів ступінь відкритості Китаю поступово зростав. Під впливом західної культури, порівняно з минулим, вона стала вже не настільки консервативна і традиційна.

Як висновок хочу зазначити, що час гарно впливає на стереотипи зарубіжних студентів щодо китайців. Після перебування у Китаї та спілкування $з$ китайським народом, іноземні студенти мають змогу помітити динамічні зміни своїх стереотипів щодо китайців, що, звичайно, позитивно впливає на розуміння Піднебесної.

\section{БІБЛІОГРАФІЯ}

Cuddy, Amy J. C. et al. 2009. Stereotype Content Model across Cultures: Towards Universal Similarities and Some Differences. "British Journal of Social Psychology" № 48: 1-33.

Jin, S. 2005. Social Psychology (社会心理学). Beijing: Higher Education Press.

Li, Y. \& Fan, J. Foreign Language Teaching and Research (外语教学与研究), (2007).

Katz, Daniel, Braly, Kenneth. 1933. Racial stereotypes of one hundred college students. "The Journal of Abnormal and Social Psychology” № 28(3): 280-290.

Colin Ho, Jackson Jay W. 2001. Attitudes toward Asian American: Theory and Measurement. "Journal of Applied Social Psychology" vol. 31, issue 8: 1553-1581. 姜良杰、汤明润. 2012. 来华留学生跨文化适应问题及对策. “人民论坛”第 5 期.

丁慧芬. 2011. 蒙汉大学生民族刻板印象的结构及差异研究. 内蒙古师范大学硕士学 位论文.

管健. 2009. 刻板印象模型从内容模型到系统模型的发展与应用. “心理科学进 展”第 4 期. 


\section{W POSZUKIWANIU WIEDZY O NIEBIAŃSKIM IMPERIUM. OBALANIE UKRAIŃSKICH STEREOTYPÓW NA TEMAT CHIN}

Streszczenie: Artykuł analizuje stereotypy zagranicznych studentów chińskich uczelni na temat Chińczyków oraz wpływ stereotypów na kształtowanie się światopoglądu studentów zagranicznych na temat Niebiańskiego imperium. Wyniki pokazały, że studenci zagraniczni zmienili swoje nastawienie do chińskich studentów po studiach w Chinach.

Słowa kluczowe: stereotyp, chiński charakter narodowy, kultura, symbol, obalanie, Chiny, Ukraina.

\section{У ПОШУКАХ ПІЗНАННЯ ПІДНЕБЕСНОЇ. РОЗВІНЧАННЯ УКРАЇНСЬКИЙ СТЕРЕОТИПІВ ПРО КИТАЙ}

Анотація: Стаття досліджує стереотипи іноземних студентів китайських університетів про китайців, та вплив стереотипів на формування світогляду у іноземних студентів стосовно Піднебесної. Результати показали, що іноземні студенти змінили своє ставлення до китайських студентів після навчання у Китаї.

Ключові слова: Стереотип, китайський національний характер, культура, символ, розвінчання, Китай, Україна. 